1 今 抑 る

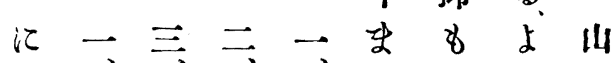

は鞍普大鞍で南り東

花山蘭平山に霂て 少

嵐店店山店應洲大の

第片地西 及地用鐵連東

主磨方方大方地道地北

琵岩の の 石の 質會方部

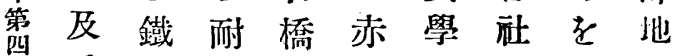

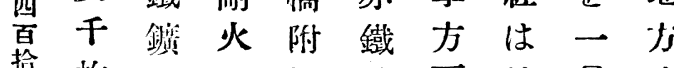

拾枚は粘近嵈面地見は

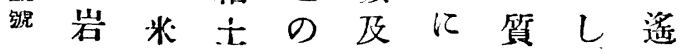

䧕莎磁貢調又见

有大培鐵獻查南渤

說

1: 地

盤方

にの

はそ

粒れ

狀

硅 類

万 閉 洲 簒

は始 鐵 ‘

次し道隔

ऽ 會 $\tau$

重よ佂り

大り地遼

石 似

な已質 來

ㄴ.

序第 栗

× ᄂ

頂 前

け寒

章附

近

芝尘

秠地

附 形

近及

之地

亲位

b武

るに調本

新十查島

發星 所と

地 筫

質

三t

整

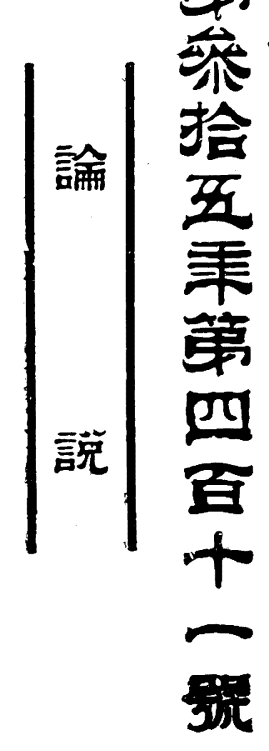

見霜を相

をを見龂

宗經 學 し

せ九し地

亞

紀

る 万、遧質

2 而東 學

とし本上

小鼠相

中

b。該地連

地 質 續

質の世

調 概 る

查 念 加

事を 如

業得く

吕た思

現 $b$.

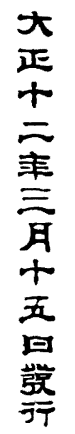




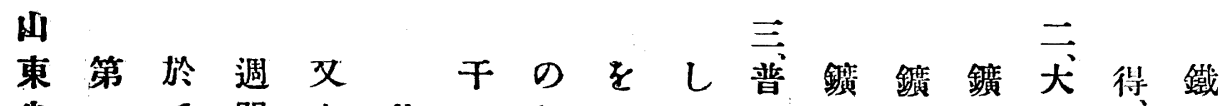

牛一七 間山宕の 姆促炭蘭と用は石鋹鑛

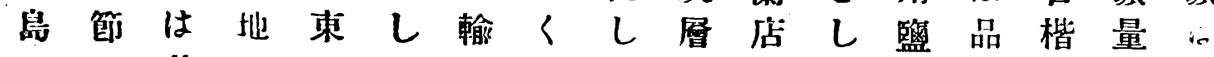

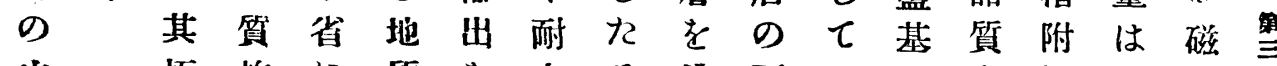

山地極旅に質を光る 構西は性良近極鐵京

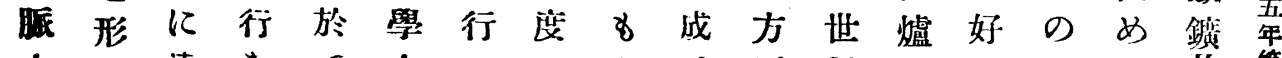

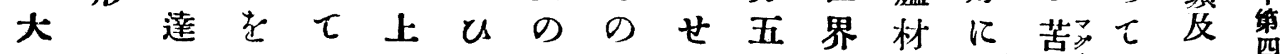

系しな見山䖪なし湖最とし 蓄豐赤

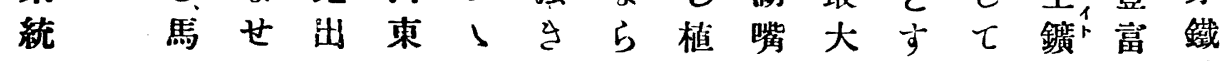

は車 少さ牛あ粘九物炭なる 耐はな鑛

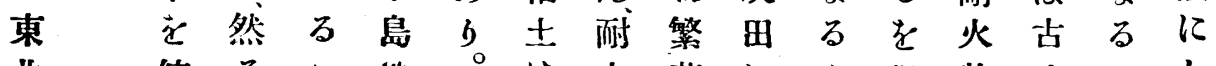

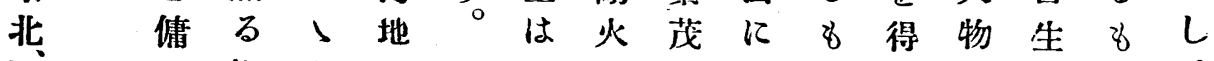

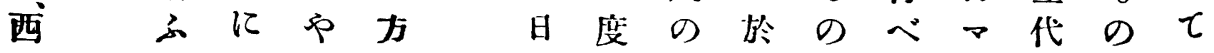

南事當的か 本の祭け市しが古り其

な 能時計遼

5. は排 5 島

而ず日れ牛

l. 又思卞島

$\tau$ 宿 想 此と

此所 到 關 連

のをる係 誉

山得所をせ

脈 るに 明 る

は に盛にる

大困にせの

に强其る ら鑛 ネ 則姫含

於导䇆耐 九床シ のし鐵

て 8 根火少はア白

はのに粘。廣七雲

稀はよ土土區 メ岩

にゼりは域ンす

見に士三に泫

沙 $>$ 石

るケ 中 溜

b グ 灰

もルよ 紀

$\begin{array}{llllll}\text { の } & \text { 錐 } & b & \text { 含 } & \text { 其 } & \text { 分 } \\ \text { 小 } & \text { 三 加 } & \text { 炭 } & \text { 磁 } & \text { シ } & \text { の }\end{array}$

體難しんな

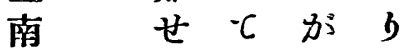

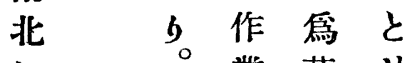

に

流

菜芝 せ

る十里 層

量 $ア$ 全

が四をに實監部

故"番脫屬 に類苫

に独却し三の土

巳忞常百原に

容 喿ば

に示しに

佶 料

年しめ炭

噸と交

な渡速

々 鋌以 層

にし 代

日 量 $\tau の$

達て せ

ず該 如

に

殊 地 矛

本又耐底

す用る

$\tau \quad$ 方 特

に䄼 火 盤

恐途 8

區威に殊

间高土を

ら届の

つなの李

<くな

品

位

は

劣 地

分海七鐄

て b向す

笘 齐

5

衛約床

若此上蓋

土製 該

等

な

る

8

磁

石

選

䥊

に

よ

b

$\tau$

品

位 三

良念

に

な 
るる謂にか に方他豆し所流のる

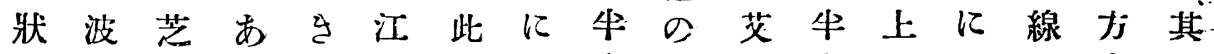
態狀眾り川は海於島一山島訅ては向結

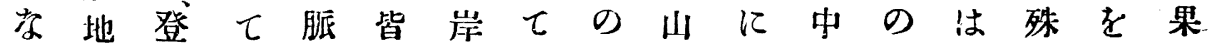
b.を州海は北山上東脈し主關片ど前各 第波形間拔讪飞脈訅南市儿要係麻此寒部

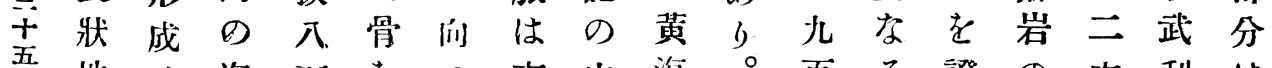
年地せ海百走つ南山海。百る證の方利は 筧は $、$ 岸五悲 $\tau$ 北脈に五山明走向亞南 页濑此地十は山にと沿十脈す向の紀北 揞次上畄米し地走相及米はるは對後に

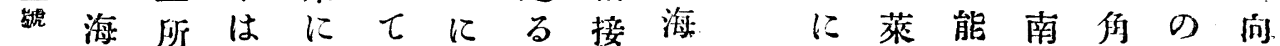
訜岸々制及數玲河し岸達山は北線褶つ

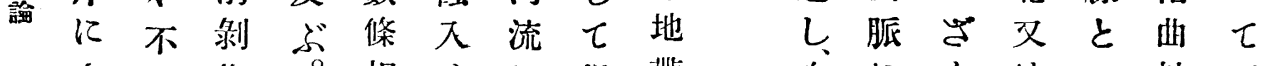

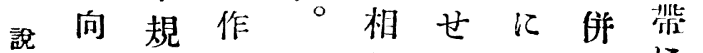
次にbは 一 軸延 つ則用併 3 小走に は し 马 束致を長

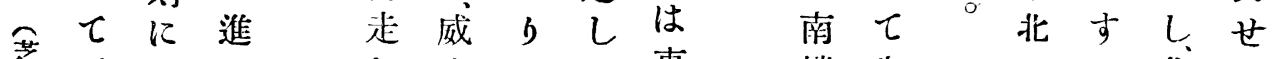

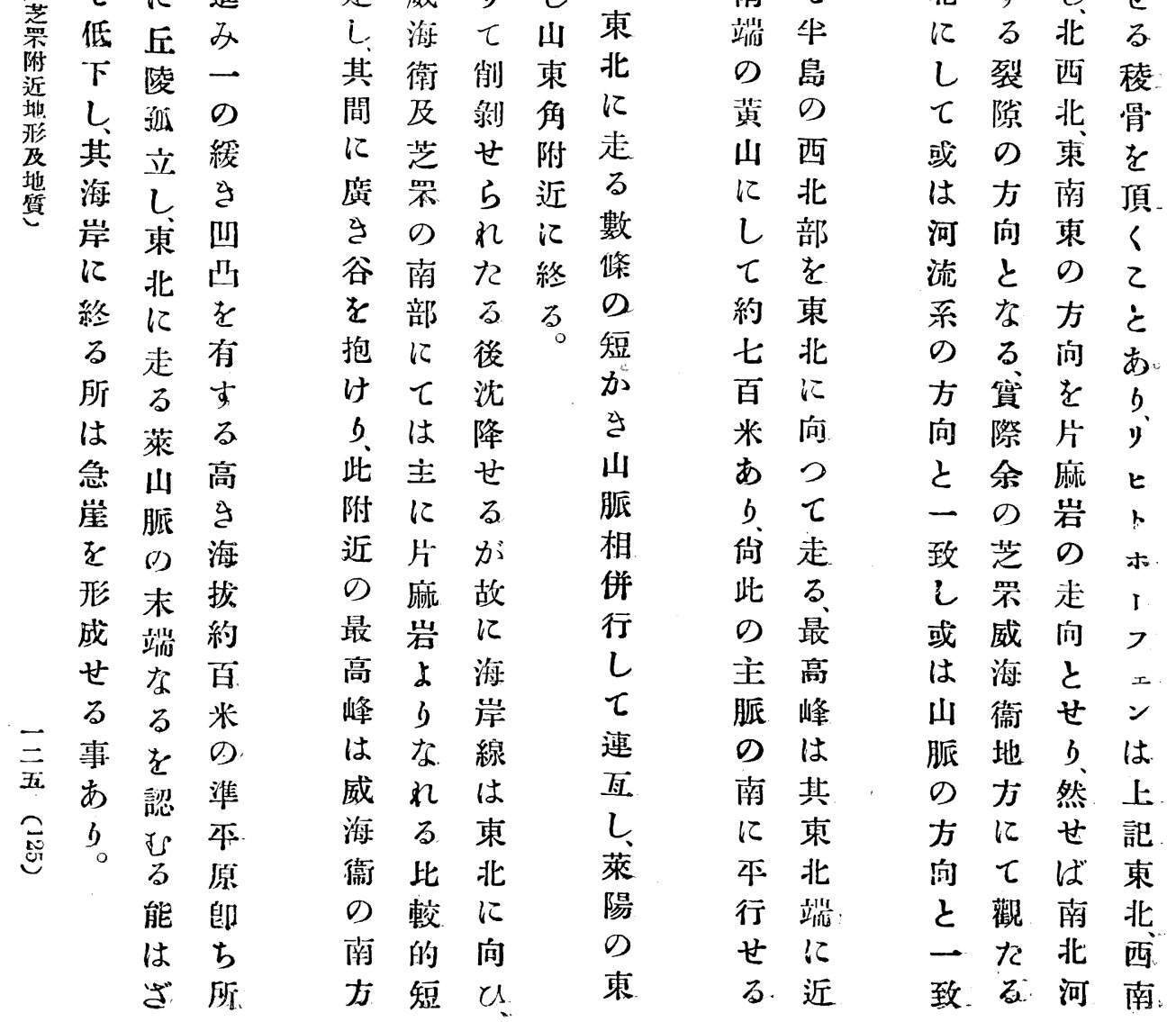




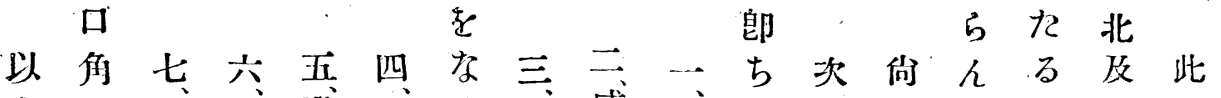
上之萊咀登尤世芝威東に噴。な北の 突同州口州十 5 罘海方山出 5 根如 角嵄のの東里。附衙飞束岩故は己 のに西角方舖沂の於牛は波波 成西北文の㳊 因方飞㔔岬 $b$ 於角は はに一陸角東䍇 龍 突 乫緽は北

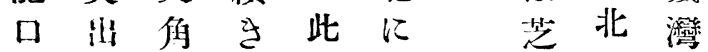
哭せ南の方突嘼方の 角る了島に出自に等 及陸附に突世市向角 萊續近儿出る り。分即 州さに $\tau$ 乙 岬 奧 ち 突の芙西其市地山 何岛蓉方附 b少束 乲島飞近六

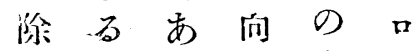
けべるつ島、 ばしをて 舆 ピ 他。以乫と ン はて出相グ 山假せ連角 束 万名。

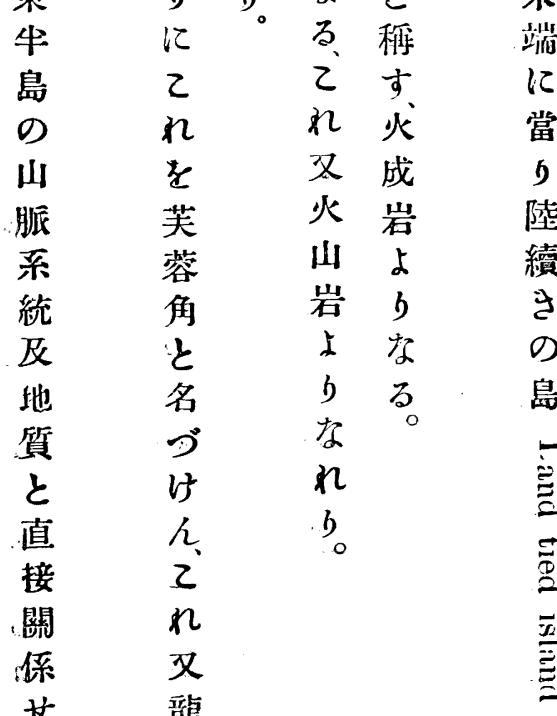

与角
來束

的方

る 江

山

脈

の

末

端

に

當

5

陸

續

$$
\text { a }
$$$$
\text { の }
$$

島

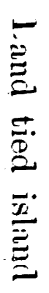

島 前

の 訅

北 波

及 狀

西 地

侧の

の 單

海 詶

岸走

線 破

飞 $b$

沿 $\tau$

及 高

$\tau<$

地 鄖

形 ゆ

向者

3. -2

暼と

せ あ

ん

に

此品

の I

侧 ビ

にン

於 グ

乙 角

はの

所 如

\&

U

笑

角

あ

b. ii 狀 狀等

㭽地地华

の形形第 末に面 端丈y揞 部 で ピ 㩆 は削ト 色刣 木 铪 タせ 1 㜔 の 万> 形风土茫 の其ン采 地やは逝 塊心坐嘼 $と$ 部 島 な 施の れ南西 3. 北 北 芝東海 罱北岸 島又に 㳊は於 此西 の 北 8 如飞訅 己向載 地了世 塊河 3 9 流 郎 沈飞 降七萊 せ區山实 万分脈 क せ は の 5 其 尔れ西 


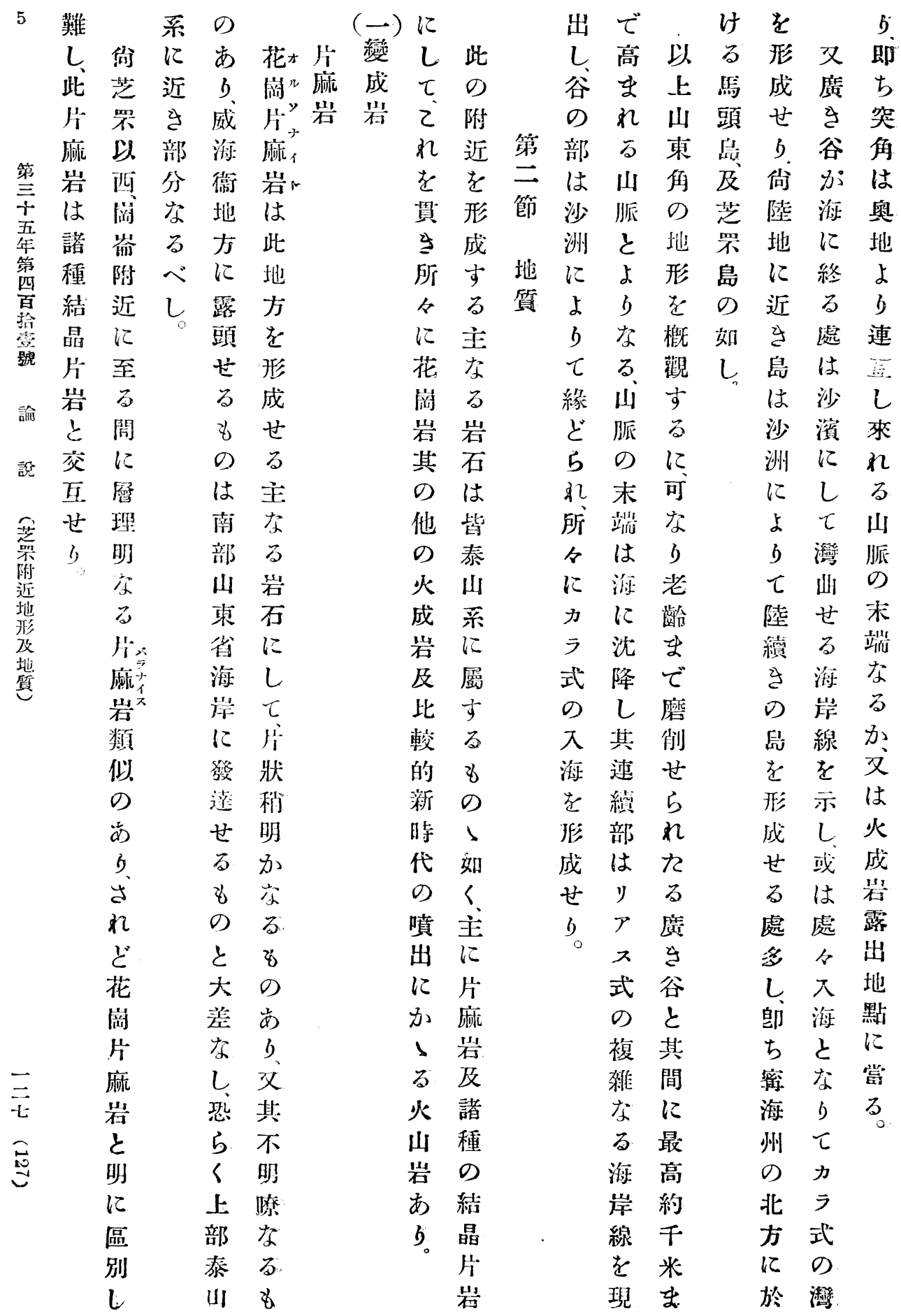




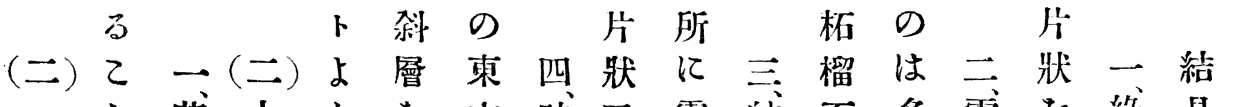
ペと花火与方硅又露結石多雲を線晶

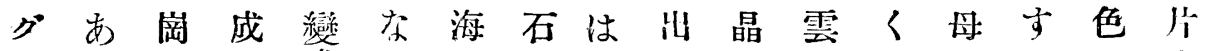
$\checkmark$ b岩嵿成せ頭带し質母の片る片岩 夕又花せるの主狀版石片炻岩岁岩

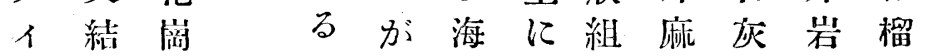

、晶岩 片は 芝岩花 罱の萹 蜜。間 片 海 に 麻

州介岩

問 在 露 の 頭 道万地 路はの 飞芝 所 沿嘼 多 3. $に$ 上西市 馬 郊 $b$ 山に例

寨於 人

のてば 北具 威 方 海

に。微

此茫

岩紧

石間

あ の

3. 道

䔔路

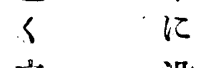

之 沿

tres

望扫

め見

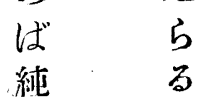

8如岸石織岩岩は石雪

のく、英明中(一) 附の舟 小其市よ加飞白圖紹片 る傾了方介色儿晶岩 べ科暗尔名在緻於をは

な 少 总麻 し 三色 3 厚世密七含灰 十結長層多は中尔

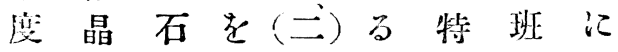
乃質を极結方別狀し 涳石含し晶のに艺て 近灰乱質あ斜呈長 十岩肉版石了本せ石 度及色岩灰多行了, 及 梠堅乃と岩く線其緍 b母至交ははに柘雲

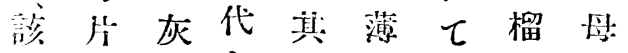
岩岩色し色層示石よ

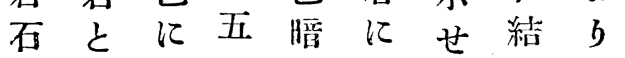
は交し十品しb晶子 恐互て里学て。のる らせ曆舖る茫大就 く负狀》名置标中同 牌走則西のの茫時

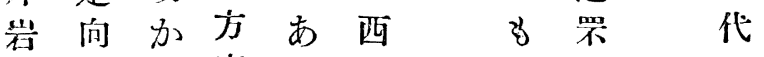

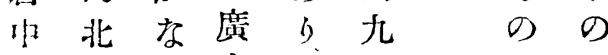
に八ら大粗十は西 皟十ずな質里徑部 诎度此 る せ東岩地し 附

崖 西に石老儿近 籷 亿 ぺしは占雲辛涪露 グて五导母店達出 
7 角高尓了要麻面所北晶白

のさす文此 (三) ○岩該四表皘三儿六む色

間二を海の冲米を玄玄は江石幅十与口

の十得岸地積は被武武し沙英二度な丘

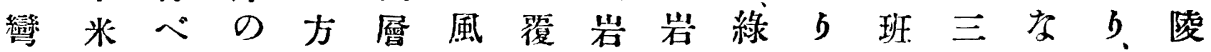
第入をし、砂の 化せは色石岩糎 多多海

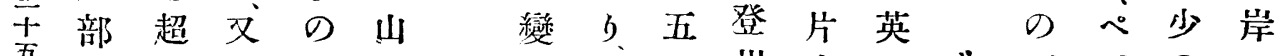
落にゆ海中は質下十州岩斑り石グのに

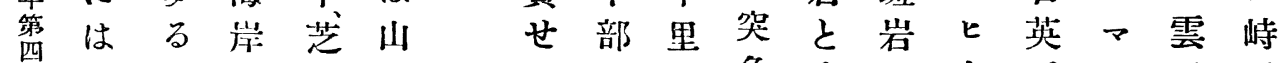

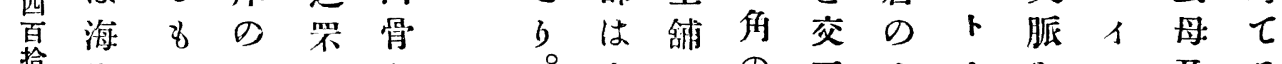

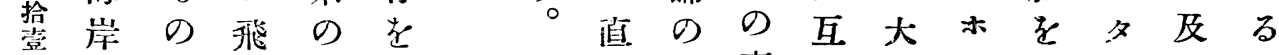
路に少砂西露接北東せ露了其1角が 諭沿なは郊は 片榇牛る頭 7 中: 閃如 嫲家部如あ土に石し 鿁又と口あ植 はせ附る物

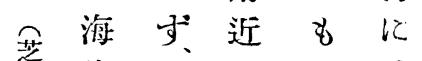

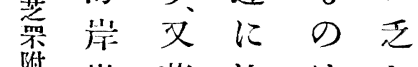
崖芝沙はし の栗 丘赤冲 前の色積 方 東形 柘 層 に馬成榴は は山せ石山 海塞るを簏 濱 孔 所含 就 と蒙あめに の潭 b 3 廣 間附芝之虽 飞近眾れ谷 厚深の专に 当交西利の 沙沙福用み 層 丘山し 弡 一あ市夥磨薘 三 3. 万、の 砂 し 前な北又耕

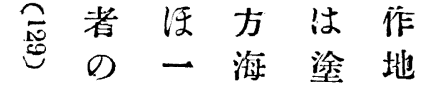
場 般岸壁と 合にに用な に乫はとれ

にの形見在は在含れ 接海, 成ゆ傳九海明さ附 し岸し份へ十を睹此近 其飞多此九里隔な所の

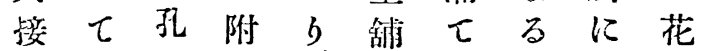
觸は質近該とれ片於烱 部走暗に石七る狀て片 向黑は苦十對をは麻 五六色綠致里崖呈花岩 米十の色岩舖馬し曒を 乃度溶のはと頭走片貫 至西岩閃花のに向麻け 三傾に綠南間为北岩る ○斜し 岩岩の亦五は好 米束 $て$ 狀と又同十走の の北橄 の似口樣度向に 部四欖岩て、の東北し は十石脈る比岩傾三て 柱隻を多るン石斜十石 狀の含しのの゙市北度英 覔め。解る三西長 劣位るし附分十に石 し事视近如度しの 表有あ多にしにて大 面す 与。少於。乙傾标 部る層て死斜る 約片狀展所東結 


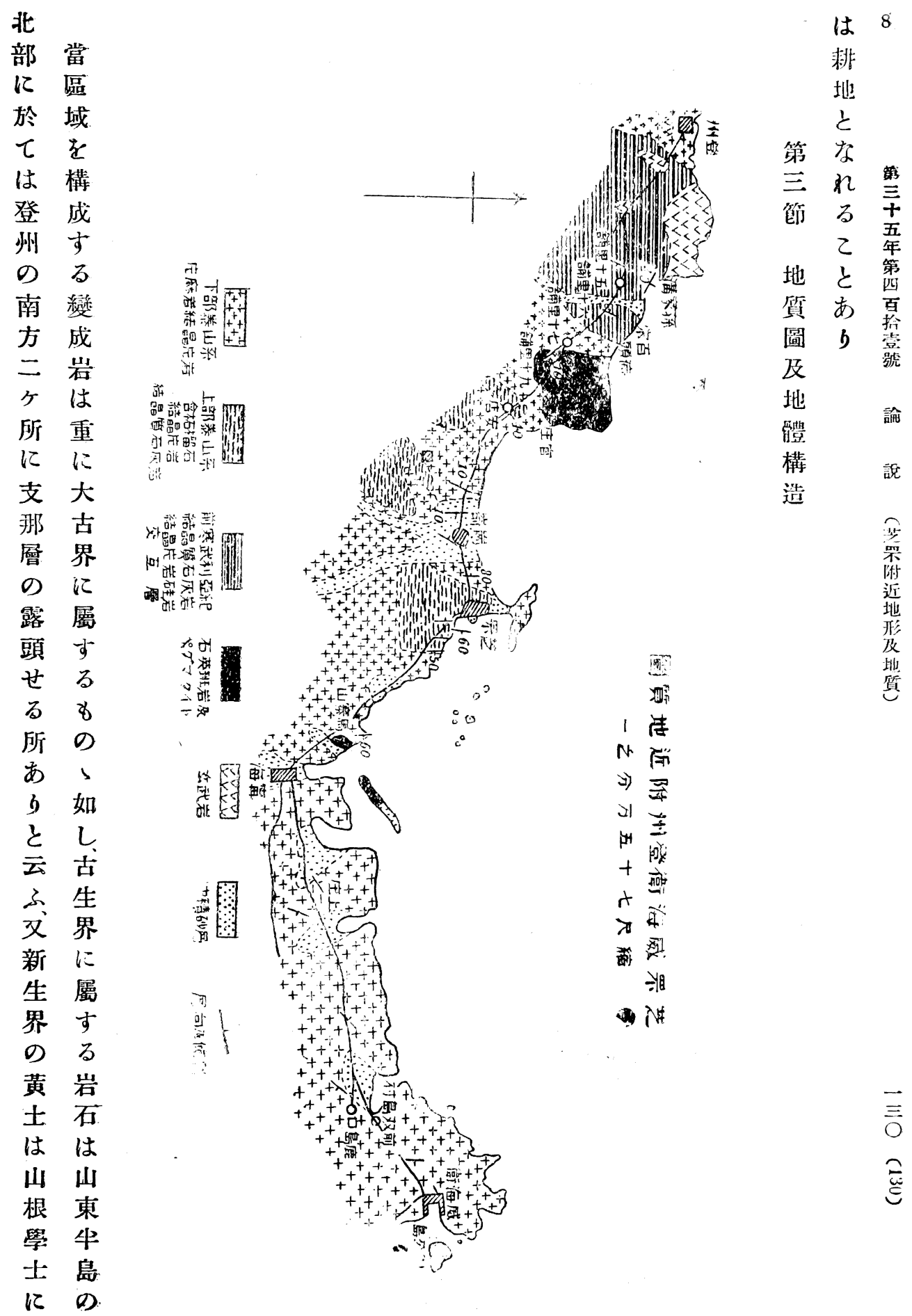


9 片蔄從 岩芝て片次注大易等 前の也上如下次人。 白嘼威, 麻に意孤にの 寒如 b部さ部には 色附海岩詶を山罥累武 己片泰之泰圖黄

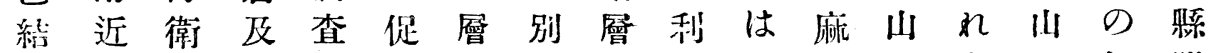
第晶及突雲區せのせ晋 せ 声筫角母:域 b 下 5 山紦劣の 吾石以に片內。部る東? 亭芝。花に山

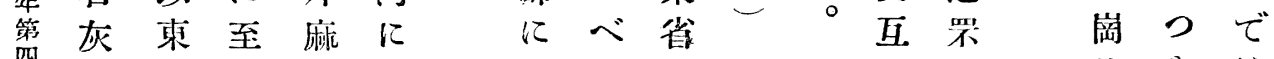

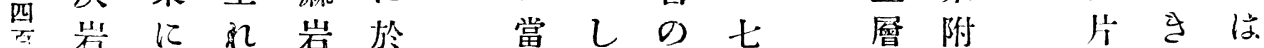

境暗於ばより

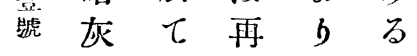

\section{色は ひな地}

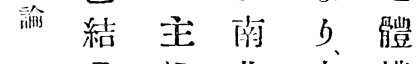

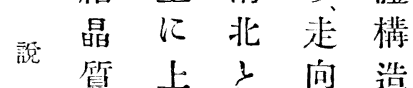

石部なは社

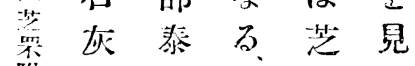

附岩傾罚

地系科附に

裂硅岩は近芝

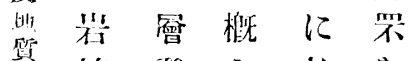

算等發し於考

に爑てて中

し まは心

七 与南と

五岩度北し

小石乃斯

里は至近東

舖花六く方

附阙十寧は

近片度海重

の麻な州に

渡岩与以下

三 岸 のと 東 部

三に外すに泰

至於含。於岒

焉て柘係

は榴はに

暗石梷し

灰雲 北 $\tau$

色目花
當しの 七 曆附

b y 他 +

上的の里

部ど部佰

泰 硅に登

山岩發州

系老蔆閏

の介す

最在る發

上す上蓬

部る 部 せ

な 默 泰る

ると. 山片

へ石系麻

乙灰它竖

故岩其 谙

にの整 色

之比を結

を較罣晶

前的に誓

塞厚し石

寒 愿文灰

武を關奀

利有東 紽

亞方州色

紀るの片

點大芣

とと坬雲

記よ111 母:

しb檿片

七見と䆑

特风 8 硅

にば容岩
及 近

芝の

㽞含

五杯

十榴

里 石

猞雲

間 扵:

に

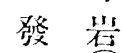

蓬圆

せ に

るは

望 注

母 意

片专

岩引

片 <

麻 爫

范女

白 特

色 に

結 區

晶别

質 世

石る

灰 尔

岩 行

の 線

交に

代七

留 示
麻七可

岩記な

片する

麻。發

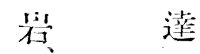

片等

岩る

䉼如

ब) वे

交政

互此

せ . 附

る 近

812

ஏ は

に著

L L

c

芝喿占

威

海

衛

間

に

發

迩

す

る

地

䉡 


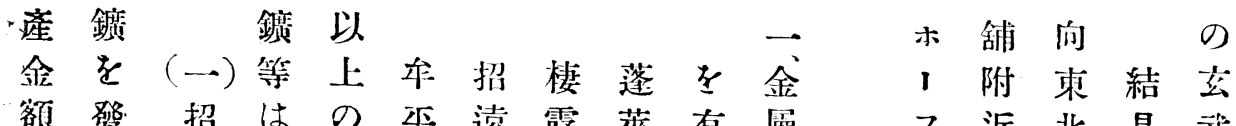

额墢招はの平遠霞萊有屓入近北晶武

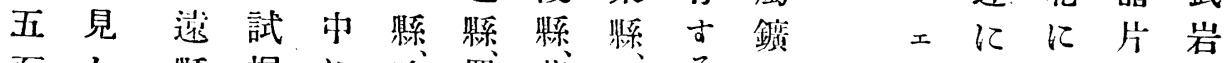

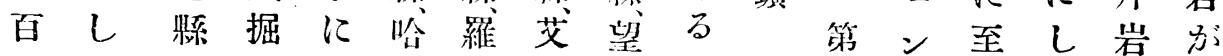

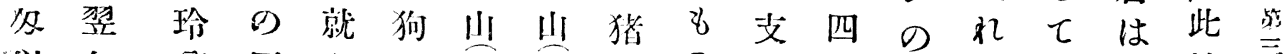

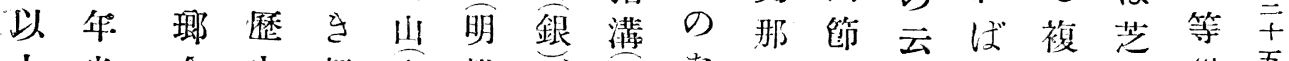

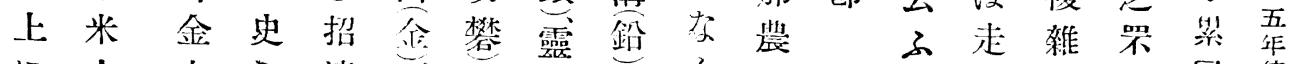

に人叫を遠鍓馬川金了工山如向な附曆察

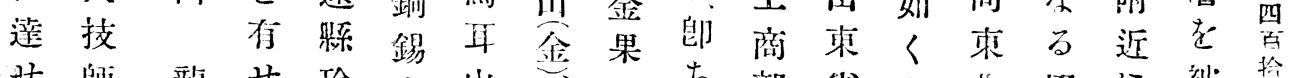

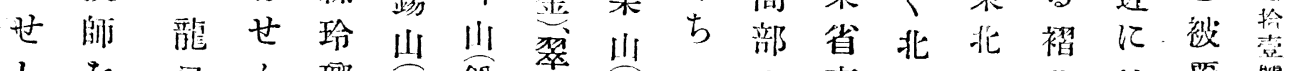

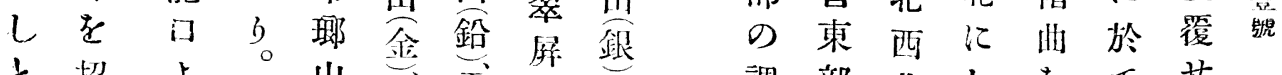

と招よ山㻗雾㺫調部北しをてせ

云聘 b は

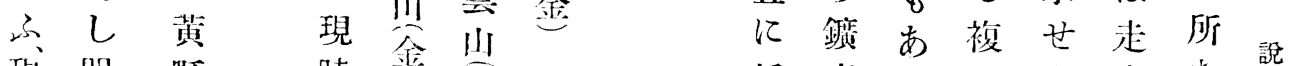

今琴阙㮩時金不

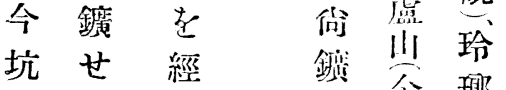

道 5 少金唧

八朋洷六

治れ证金

鍰 一 道

脈年九命金

は頃十を

片南支保

麻 万里水

岩数な b

中年方发

の留测牟

石は治本

英使 二郡

脈用十金

に人二, 牛

し夫年师

几李版

鍍千宗威

石人岱海

の一比衛

品日 吕の

位 の該金

係產れ雜方而市

る地どな哂北

鏣大る十西蹗

山體褶里北逝

表袹曲堡に堆

中曲を附し菠

$\begin{array}{llllll}\text { 登 } & \text { 表 } & \text { 近 } & \text { 坆 } \\ \text { 川 } & \text { 方 } & \text { は } & \text { 一 } & & \end{array}$

府向也於の

管

內 - 裂活科

の致す更層

分するにを

丈べに走尔

けし此向せ

飞附西 る

$\tau$ 沂 北

十 $の$ 傾 如

四地科

あ層東 筒

b の 北 崙

皆走と地

探向尔方

掘は 3 に

の リ五て

歷比は

史年是 


\begin{tabular}{|c|c|c|c|c|c|c|c|c|c|c|c|c|c|c|c|c|c|}
\hline 11 & & 三 & ベ & & & & 二 & 便 & 後 & & 位 & + & & 大 & & 處 & \\
\hline & $(-)$ & 本 & L & (三) & $($ (二) & の & 石 & 產 & 上 & $(\equiv)$ & な & 九 & (二) & 倉 & 產 & 理 & 最 \\
\hline & 招 & 島 & 其 & 芝 & 萊 & 原 & 材 & 出 & 海 & 威 & 3 & 年 & 金 & 組 & 金 & す & 上. \\
\hline & 邀 & は & 他 & 㧵 & 州 & 料 & & 豫 & の & 海 & $\varepsilon$ & 德 & 平 & ; & 高 & & 鑛 \\
\hline & 夥 & 溫 & 此 & 西 & の & と & $(-)$ & 想 & 英 & 衛 & 元 & 華筈 & 縣 & 關 & は & & \\
\hline 第 & 來 & 泉 & 砂 & 郊 & 大 & L & 蕜 & $\varepsilon$ & 人 & 金 & 3 & 鑛 & 金 & 係 & 明 & & \\
\hline 干 & 台 & $k$ & 中 & 海: & 理 & $\tau$ & 州 & 反 & 市 & 山 & & 務 & 牛 & せ & 治 & & 1 \\
\hline & 溏 & 富 & $k$ & 濱 & 石 & 使 & の & せ & 威 & & & 貿 & 金 & L & 二 & & \\
\hline & & 现 & は & r & は & 用 & 阿 & L & 海 & 同 & & 易 & 山 & 事 & † & & II \\
\hline & 䅫 & 调 & 他 & 柘 & 绻 & せ & 夜 & 艺 & 衛 & 市 & & 公 & & あ & 三 & & \\
\hline & 城 & L & に & 榴 & 種 & 5 & 五 & 以 & 鈔 & $\sigma$ & & 司] & 本 & $b$ & 年 & & \\
\hline & の & $\tau$ & 利 & 石 & の & る & 支 & $\tau$ & 山 & 南 & & 試 & 鑛 & と & 開 & & \\
\hline 論 & 㷊 & 現 & 男 & の & 器 & 1 & 星 & 明 & 會 & 三 & & 掘 & 山 & 云 & 始 & & \\
\hline & 郊 & 時 & d & 砂 & 县 & か & $\sigma$ & 治 & 形: & 十 & & せ & は & 3 & 以 & & \\
\hline 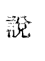 & 川 & は & る & あ & k & 如 & 把 & $\equiv$ & 存 & 支 & & L & 嘗 & & 來 & & \\
\hline & t? & 袺i & ベ & ) & 造 & L. & K & 十 & 設 & 里 & & 8 & $\tau$ & & 四 & & \\
\hline & 覆 & E & ᄅे & 壁 & 作 & 附 & 鼣 & 九 & II & 臥 & & 未 & 馬 & & 百 & & \\
\hline & $\tau$ & t. & 鐄 & 芯 & せ & 近 & 石 & 年 & $L$ & 毕 & & 於 & 建 & & 餘 & & \\
\hline & $b$ & 人 & 石 & 塗 & 5 & に & 克 & $\mathrm{H}$ & 此 & 山 & & 採 & 忠 & & 琶 & & \\
\hline 把 & 僅 & 0) & 老 & る & 礼 & 日 & 座 & 止 & 探 & $k$ & & 掘 & な & & 其 & & \\
\hline & に & 沐 & 見 & 㸝 & 建 & 琹 & す & L & 掘 & あ & & $k$ & る & & 價 & & \\
\hline & - & 浴 & 出 & l & 築 & 壁 & る & 同 & 權 & 3 & & 至 & i & & 格 & & \\
\hline & 支 & $k$ & す & 供 & 材 & $\theta$ & は & 會 & 老 & 古 & & 5 & D) & & $=$ & & \\
\hline & 里 & 供 & 사 & せ & $c$ & 多 & ) & 社 & 得 & 米。 & & ず & $\overrightarrow{.}$ & & 百 & & \\
\hline & (1) & せ & 8 & 5 & せ & さ & E & は & 72 & 金 & & $L$ & 度 & & 餘 & & \\
\hline & 地 & $\dot{b}$ & 知 & る & $b$ & は & ト & 解 & $b$ & II! & & $\tau$ & 探 & & 萬 & & \\
\hline & $k$ & る & れ & ベ & る & 2 & ホ & 敨 & 而 & と & & 中 & 掘 & & 圓 & & \\
\hline & あ & 1 & ザ & く. & 0 & 12 & I & せ & L & L & & 止 & せ & & $\varepsilon$ & & \\
\hline & 3 & の & 注 & 又 & & か & ᄀ & 3 & $\tau$ & $\tau$ & & せ & L & & 推 & & \\
\hline & 官 & 外 & 意 & 撙 & & 爲 & $x$ & & 吗 & 名 & & 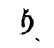 & 事 & & 測 & & \\
\hline & 民 & な & $\frac{9}{9}$ & 砂 & & な & ע & & 治 & あ & & 鑛 & あ & & せ & & \\
\hline & 及 & b & べ & 金 & & 3 & \$ & & 三 & $b$ & & 石 & る & & 5 & & \\
\hline & 女。 & 8 & 2) & 甽 & & & 已 & & + & L & & $\infty$ & 8 & & る、 & & \\
\hline & 掂 & & 8 & 砂 & & & 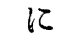 & & 六 & 分 & & 含 & 中 & & 青 & & \\
\hline & に & & の & $\check{\varepsilon}$ & & & 記 & & 年 & 英 & & 金 & 止 & & 島 & & \\
\hline$E$ & 澏 & & な & L & & & 戴 & & 探 & 國 & & 分 & せ & & 戰 & & \\
\hline & 別 & & 3 & $\tau$ & & & せ & & 堀 & の & & + & 3 & & 役 & & \\
\hline 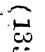 & せ & & ${ }^{\circ}$ & 优 & & & 3 & & $\kappa$ & 威 & & 䓵 & 共 & & 後 & & \\
\hline & 5 & & & 用 & & & 白 & & 着 & 海: & & 分 & 後 & & 一 & & \\
\hline & b & & & せ & & & 色 & & 手 & 衛 & & 之 & 朋 & & 時 & & \\
\hline & & & & 5 & & & 塗 & & せ & 租 & & $\because$ & 治 & & 久 & & \\
\hline & & & & る & & & 料 & & 1 & 借 & & 二 & 三 & & 原 & & \\
\hline
\end{tabular}




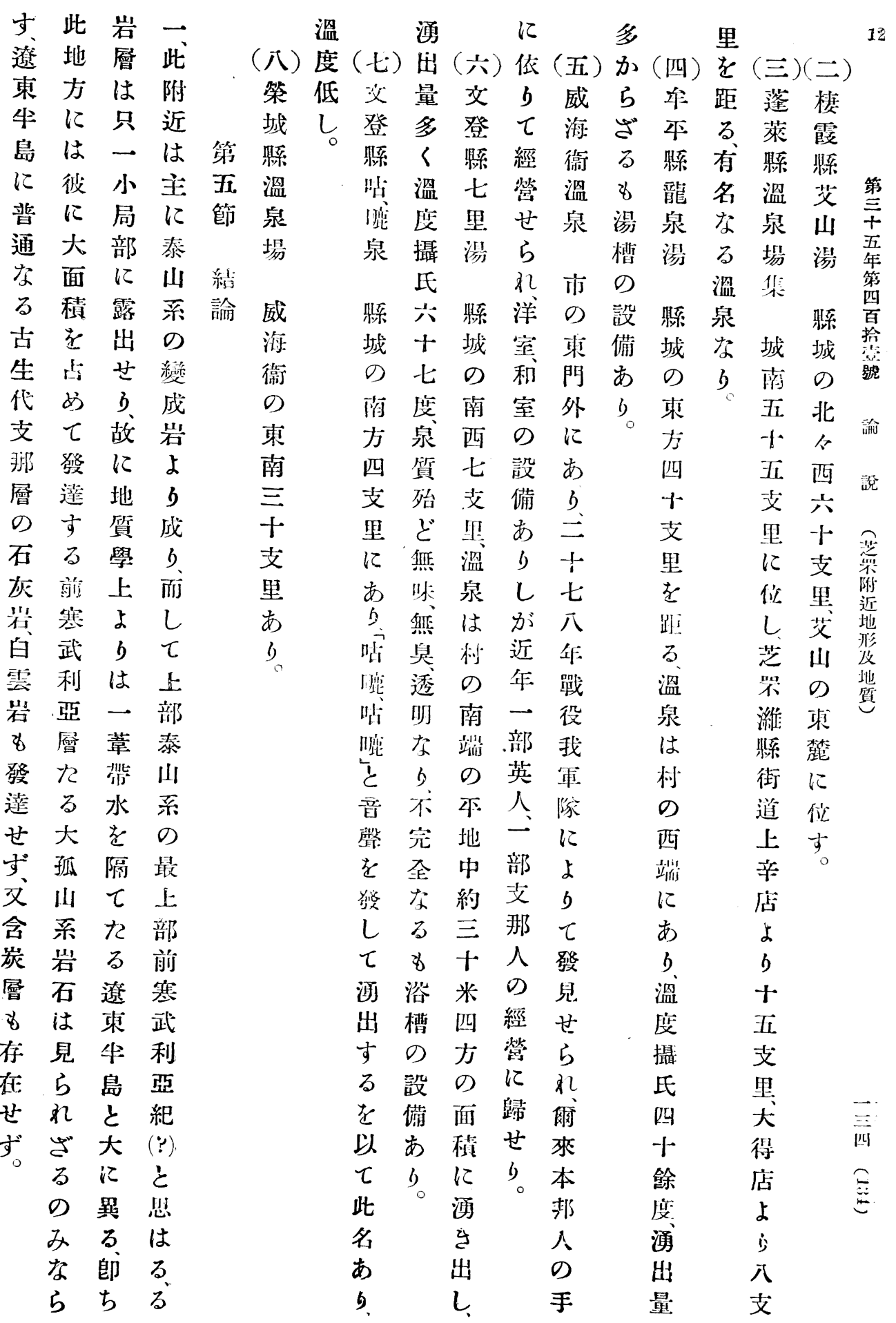


五なあ四学三北三

要 ら几有安岩線此

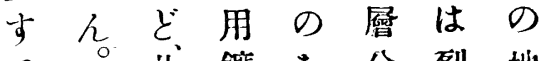

る。共鑛を分裂地

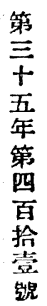

にに物見布隙方

山著の 出よのの

東し主しb方岩

半少能推向愿

島 万るはすな走

の ずはざにる何

末 溫金る山出に

端泉䥊べ東如は

険

部はにし半し 西

は八し 島北

說

有ヶて部南

用所花 $飞$ 北

鑛治禺

物涌片洦北

に出麻 は 等

そ せ岩遼市

乙 万中東中

皆の 牛 と

地 恐石 岛 白

方 万英深

なく脈於北

b泰に け は

夈山脴方主

$\begin{array}{ccccc}\text { 完 系 } & \text { 胎 } & \text { 如 } & \text { と } \\ & \text { 岩 } & す & \text { ๖ } & \text { し }\end{array}$

層る鐵列

の が 鐄 大

裂如床體

隙し苦落

に此士 脈

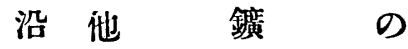

$\overline{\underline{F}}$

es 及 方

上は耐向

昇石火炎

せ 材 粘 一

る 所 士 致

$\begin{array}{llll}8 & 9 & \text { の } \\ \text { の } & \text { 如 } & \text { 南 }\end{array}$ 